a

pota.t.

and

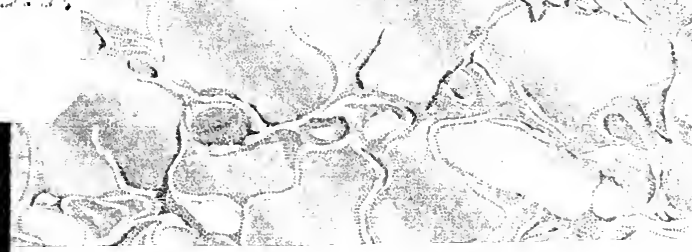

$1,1+4$

$-0$

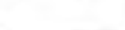

2
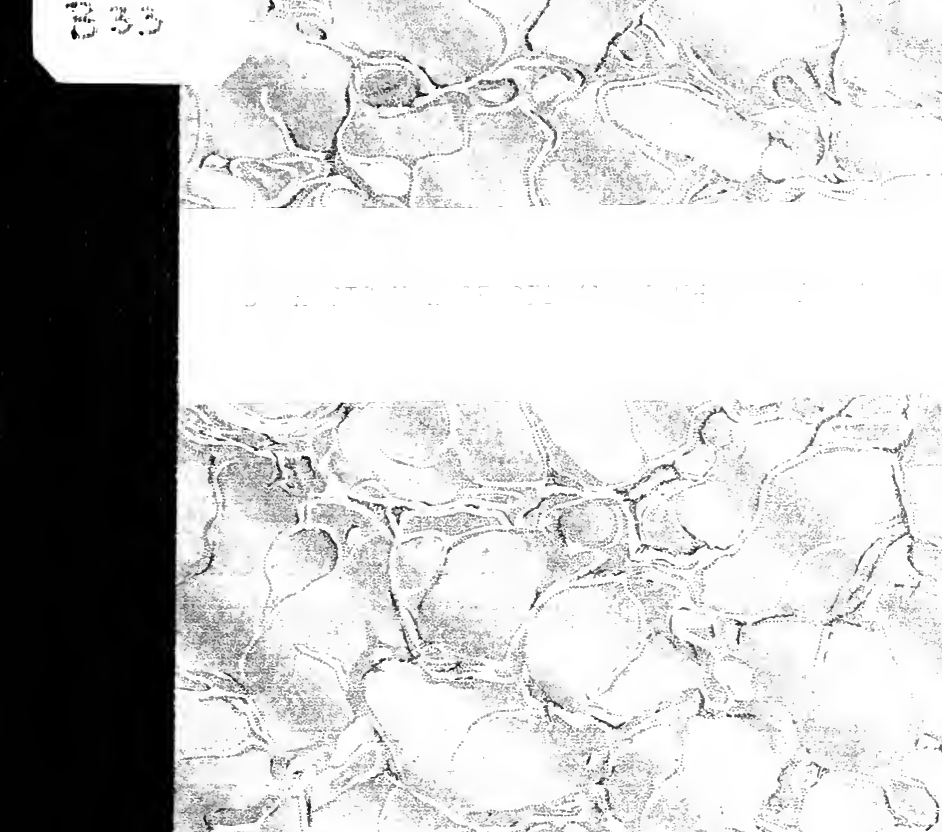

\title{
.
}

1 r.

$(2<)^{4}$

and<smiles>C[Te]=[Te]</smiles>

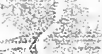

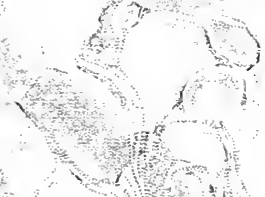

$y+2$

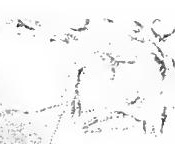

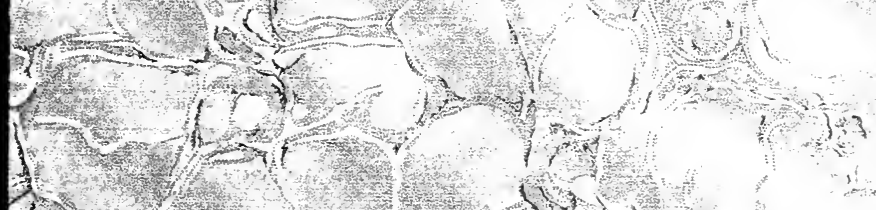

(N)

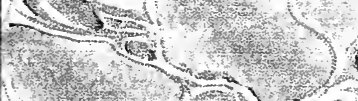

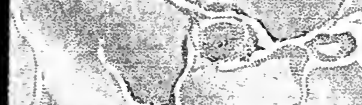

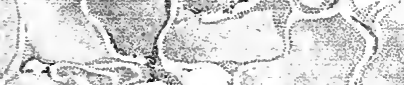

$\frac{1}{4}+1$

3

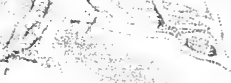

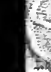

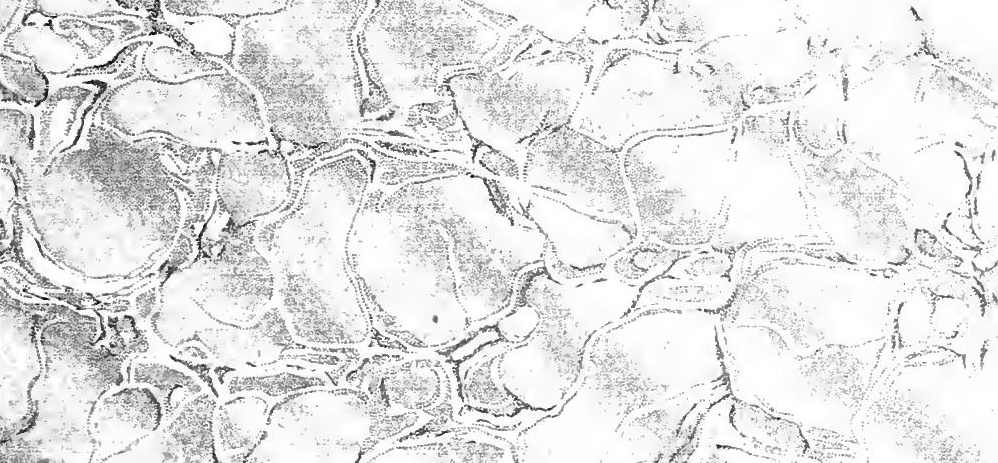




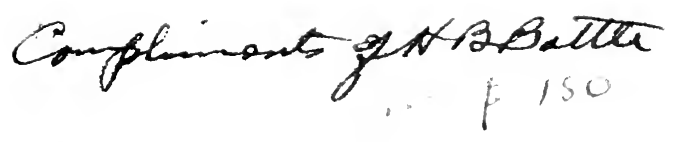

THE DOMESTIC USE OF OIL AMONG THE SOUTHERN ABORIGINES

By Herbert B. Battle

[Reprinted from the American Anthropologist, Vol. 24, No. 2, April-June, 1922.] 
The

\section{Howell Collection}

OF HISTORICAL MATERIALS

Presented by Kay Kyser And his Míother

Emily Royster Howell Kyser

As a Memorial

To her Brother

Edward Vernon Howell

Dean School of Pharmacy I 897-I93 I

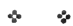

THE UNIVERSITY

OF

NORTH CAROLINA

LIBRAR Y

$\mathrm{C}_{\mathrm{P}} 970.01$ 
THE DOMESTIC USE OF OIL AMONG THE SOUTHERN ABORIGINES ${ }^{1}$

\author{
BY HERBERT B. B.ITTLE
}

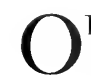

IL and fats are very closely allied in their chemical relations and their domestic uses, as well as in their other properties, and the two can not well be treated separately. Basally they consist of carbon, hydrogen, and oxygen. Less fundamentally they are chemical combinations of glycerin and certain acids among which may be mentioned oleic, palmitic, and stearic acids. If oleic acid predominates in the compound it is liquid and forms what we know as oil. If palmitic or stearic predominates, it forms what we know as fat. This brings us to other properties of these compounds, and we can subdivide them into those of vegetable and those of animal origin, with liquid and solid properties at ordinary temperatures. Oils and fats of this character differ essentially from the oils of mineral origin, such as petroleum, from which are produced mineral lubricating oils; we are not concerned with these latter in the present paper. Mineral oils when heated distill off without change of properties, while animal or vegetable oils when heated are decomposed with the loss of their properties and chemical nature.

Attention is called to the very important property possessed by some of these oils of absorbing oxygen from the air, with a resultant change of their properties, and especially one which causes a hardening in their nature. This fact gives us the drying oils such as linseed, the non-drying oils such as peanut, and the semidrying oils such as cotton seed. For obvious reasons the drying oils are used at the present day in paint mixtures. The non-

${ }^{1}$ Presented at a meeting of the Alabama Anthropological Society held March 10, 1921, at the aboriginal cemetery at the mouth of Pintlala Creek, in Lowndes County, Alabama. The author is a member of the American Oil Chemists Society. 
drying oils, as well as the semi-drying oils, are very widely employed because they are edible, and because of the facility with which they can be further used in producing solid food, such as margarine, butter, etc. These oils are varied considerably owing to the fact that they may, and do, contain one or more combinations of the oleic, stearic, or palmitic acid with glycerin. For example, the semi-drying cotton seed oil contains mainly the glycerin combination with oleic acid, as well as with stearic. The latter, when the oil is chilled by cold, becomes visible, settles away from the oleic acid solution, and becomes solid, dissolving however when the oil is warmed, and forming again the original liquid. Animal fats contain a preponderance of stearic acid with glycerin, and are accordingly solid at ordinary temperatures. They also contain the oleic combination in proportion, varying according to the source of fat. This property gives fat its oily touch and greasy effect.

Before leaving the chemical portion of the subject it should be stated that it is easy to separate these oily and fatty combinations with glycerin by the action of caustic of soda or potash, or by heat or mineral acid. The glycerin can then be preserved by appropriate means. Its uses are well known; among other compounds it forms the powerful explosive, nitro-glycerin. When oils are decomposed by caustic of soda or potash, another resultant compound is formed which we know as soap, it being the oleate, stearate, or palmitate of soda or potash. The composition is easily formed from materials of domestic origin, but the Indians did not know of this possibility. By leaching domestic ashes with water, the necessary caustic of soda and potash is secured, and by boiling with refuse fats from the domestic kitchen, or oils that are saved in various ways, a good quality of soap can be made in an ordinary boiling pot. The preparation of soap in this way was not known even to the ancient Romans, and the mighty Caesar, while using the luxurious baths of his period, had to be content with a rubbing down with oil with which ashes were mixed.

The general chemical properties of oil are as follows: Specific gravity 0.91 to 0.94 , insoluble in water, hot or cold, but soluble in various ethers, chloroform, carbon tetrachloride, and turpen- 
tine. Some of these facts were unconsciously taken advantage of by the Indians in ways that will be described later.

It is rightly to be supposed that any uses to which our southern aborigines applied the oils at hand could not have been other than the most primitive. Their mode of living would not admit of any advanced uses of these substances, or even a full knowledge of the simplest properties which they possessed. What they learned about them was due to almost self-evident facts, which came to light in connection with their daily customs. Also the sources for obtaining such oils and fats were those which commonly presented themselves in their regular pursuits, and they went no further in their search.

The oils and fats used by them were as follows:

1. Oils and Fats of Animal Origin. The principal and almost the entire source for these fats was the black bear (Ursus A mericanus), which was found throughout the whole Southern region. The nature of this animal caused him to put on a large amount of fat during the summer and fall in order that he might go into winter quarters with a sufficient supply to last him until warm weather appeared. Consequently, taken at the proper season, these bears produced large quantities of oil and fat, as well as exceptionally good meat for food. Other wild animals furnished similar material, but it is certain that bears were the principal source of animal fats. "Bear ranges" were left by the several adjacent tribes for the exclusive propagation of these animals; there no towns were allowed and all hunted in common. Such a bear range extended from Line Creek, between Montgomery and Lowndes Counties, Alabama, as far as the Chattahoochee River. ${ }^{2}$

2. Oils and Fats of Vegetable Origin. These were almost exclusively from native trees, such as the black walnut (Juglans nigra), and the hickory nut (Hickoria alba) known now in some localities as "mocker nut." Also the shell-bark hickory nuts

${ }^{2}$ A paper on this subject was read by Mr. Peter A. Brannon at an earlier meeting of the Society. During the exploration at Pintlala just before the presentation of this paper a well-preserved half of the lower jaw bone of a bear was unearthed, with wellpreserved teeth. 
(Juglans cxultata) were sometimes used. The live oak (Quercus Virginiana) yields acorns which were considered of great importance, and were much resorted to. Bartram ${ }^{3}$ during his travels through this region in 1773-1776 describes this source as follows:

The trunk of the Live Oak is generally 12 to $18 \mathrm{ft}$. in girth, and rises 10 or $12 \mathrm{ft}$. from the earth, then divides itself into three or four or five great limbs .. . sometimes to a distance of fifty paces from the trunk . . . It bears a prodigious quantity of fruit; the acorn is small, but sweet and agreeable to the taste when roasted, and is food for almost all animals. The Indians obtain from it a sweet oil, which they use in the cooking of hominy, rice, etc., and they also roasted it in hot embers, eating it as we do chestnuts.

The black walnut furnished the most desirable of all these oils, and the earliest writers, notably those who accompanied De Soto in 1539-41 through this region, were impressed with its uses, and often referred to it. Ranjel ${ }^{4}$ writes of it as follows:

It was Saturday, the 5th of June that they entered Chiaha, and since all the way from Xuala had been mountainous and the horses were tired and thin, and the Christians were also themselves worn out, it seemed best to tarry here and rest themselves, and they were given an abundance of corn, of which there was plenty of good quality, and they were also given an abundance of corn cakes, and no end of oil from walnuts and acorns, which they knew how to extract very well, which was very good and contributed much to their diet, yet some say that the oil from nuts produces flatulence. However, it is very delicious.

The Gentleman of Elvas, ${ }^{5}$ describing the stay of the explorers at this village, in another narrative written at a later date, mentions additional facts as follows:

On the fifth of July the Governor entered Chiaha. The Cacique received him with great pleasure ... and ... the Governor answered him that his gifts . . . pleased him greatly. . . There was abundance of lard in calabashes drawn like olive oil, which the inhabitants said was the fat of the bear. There was found likewise much oil of walnuts, which like the lard was clear and of good taste, and also a honeycomb, which the Christians had never seen before, nor saw afterwards, nor honey nor bees in all the country. ${ }^{6}$

In early times the black walnut was found everywhere in the interior, and in fact the Indians were in the habit of growing these trees near their towns either by transplanting or raising them from

\footnotetext{
'Bartram, Travels, London, 1792, p. 8.

${ }^{4}$ Narratives of De Soto, New York, 1904, vol. II.

${ }^{5}$ Ibid., vol. I, p. 74.

'This notable fact is also confirmed by Biedma.
} 
seed. This indeed was almost universally practised, and even now we find trees growing on these old sites. It is not to be supposed that the original trees set out by the Indians are still living, but that the ones found there are seedlings from them. They were originally planted in straight rows, and even now they exhibit the same straight lines. Three such trees are on the site of old Fort Toulouse.

\section{Preparation of Oils and Fats}

There are three ways in use at the present time of obtaining oils and fats from the living things which produce them.

1. By Rendering. This is separation by means of boiling in water or steaming, which melts out the oils or fatty materials. These, being lighter than water, rise to the surface, and can be dipped off or allowed to flow to suitable vessels for cooling and for further purification.

2. By Extraction. This method is by the use of certain liquid solvents which dissolve the oily or fatty materials very thoroughly. The next step is to distill off the solvent and to recover it for future uses, leaving the oil alone and in a purer form. In this there is always danger of contamination from the solvent, and a consequent effect upon the flavor of the oils or fats.

3. By Pressing. This is the standard way in use at the present time in the manufacture of all oils in use in the cotton-seed oil, and peanut oil mills in this region. The meats or kernels from the nuts, after being removed from the hulls, are either pressed whole or rolled or ground by means of suitable machinery, hydraulic or otherwise. Then the meats are either heated or pressed cold, the latter plan securing the better quality of oil, but yielding a much smaller output. Pressing, however, leaves a high percentage of oil in the residual cake, something like 7 per cent, and this, of course, is lost as oil, though it is of value in the cake, which is ground and used as stock food.

\section{Ancient Preparation of the Oils}

As was to have been expected, all mechanical processes among the Indians in their every day operations were of the most primitive kind. The nuts must be cracked and the kernels or meats must somehow be extracted from the shells. All of this neces- 
sarily required laborious work, which fell usually to the women. The maize or corn was broken and ground in a large wooden mortar, made from a section of a tree in which a cavity had been burned out to sufficient depth. The pestle was also of wood, and some feet in length. This operation was carried on while standing. The nuts on the other hand, being harder, required a harder surface, and more time was required to break them. This was done by means of another stone called a "hammer-stone." In many cases the hammer-stones are of granular quartz somewhat easily disintegrated, chosen for the reason that the rough surface would not slip from the nut when pounding it. It is more than likely, nay, almost certain, that the labor of the children of the towns was used to crack the nuts. The large lat stones called "nut stones" contained small cavities which were formed by hammering out with another more pointed stone. We find these at almost every village site. ${ }^{7}$

The hammer-stone was not difficult to secure, because stones of the required shape can easily be found in beds of streams, already rounded, and in many cases pointed by the water's action. The nut stones oftentimes have more than one cavity, in some cases as many as five. In this way five nuts can be cracked almost as quickly as one or two. Jones ${ }^{8}$ in referring to these nut-stones, says:

Their cavities are so located that one, $t$ wo, three, five and sometimes more nuts could be cracked at a single blow delivered by means of the circular flat crushing-stones so common.

To separate the oil from the cracked nuts, whether walnuts, hickory nuts, or acorns, the Indians knew but one way, the first method above described. They boiled the cracked portions in water without separating the meats from the shells, in a suitable pot which had also been made by the women. This caused the separation of the oil, and owing to its lower specilic gravity and insolubility in water it rose rapidly to the top and was skimmed off and stored in pots of suitable size provided with covers. This is

${ }^{7}$ Later, a number of excellent specimens of nut-stones and hammer-stones were found near the place of meeting and served to illustrate these references.

${ }^{8}$ C. C. Jones, Jr., Intiquities of the Southern Indians, New York, 1873, p. 318. 
described by Jones ${ }^{9}$ in quoting Ranjel, Hariot, Bossu, and Lawson.

The Southern Indians, especially those resident upon the rich valleys of the interior, devoted no little time and attention to agriculture. With them maize was emphatically the staff of life. Upon its nutritious properties they relied both during its milky state and when dry. . . . Generally beaten in a mortar, it was either boiled for hominy or mixed with hickory nut milk, walnut oil, or fresh bear fat, was baked into bread or fried as cakes.

In combination with corn flour and when fried in fresh bear's grease, it (starchy extract from smilax roots) made excellent fritters.

Walnuts and hickory nuts were diligently collected, cracked and boiled in vessels, when the oil, which rose to the surface, was skimmed off, and carefully preserved in covered earthenware jars. This oil was highly esteemed in the preparation of their corn cakes. ${ }^{10}$

Bartram ${ }^{11}$ also described, in 1773-76, the general practice for securing the nut oil. The unsettled oily portion was used in the nature of milk or rich cream.

I have seen above an hundred bushels of these nuts, shell-barked hiccory . . . stored up by one family [of the Creeks]. They pound them to pieces, and then cast them into boiling water, which after passing through fine strainers, preserves the most oily part of the liquid; this they call by a name which signifies hiccory milk. It is as sweet and rich as fresh cream, and is an ingredient in most of their cookery, especially homony and corn cakes.

\section{How the Oils and Fats Were Úsed by the Native:}

In order of importance the various uses of oils and fats were as follows: first, as food; second, in paints; third, in leather making or the treatment of skins; fourth, for bodily health; fifth, in hair dressing; sixth, for the rubbing and polishing of ornaments and implements.

1. As food. This use is of more importance than all the others. To the historical references already given, the following may be added, mainly from Jones ${ }^{12}$ who also states that

Under the term walnut, the historians probably included not only the nut which we designated by that name, but also the varieties of the hickory nut with which the country abounded.

\footnotetext{
9 Jones, op. cit., p. 44.

${ }^{10}$ Bartram, op. cit., p. 38.

$"$ Bartram, loc. cit.

${ }^{12}$ Jones, op. cit., p. 316.
} 
Biedma ${ }^{13}$ says, 'In the province [Chiaha] where we began to find the towns set about with a fence, the Indians get a large quantity of oil from walnuts.' At various points reached during the progress of the expedition walnuts were found stored in the granaries of the natives.

Cabeça de Vaca ${ }^{14}$ asserts that these nuts ground with a small kind of grain, furnished subsistence for two months in the year.

Jones ${ }^{15}$ also writes:

Among the natives in Louisiana the walnut was so important that the thirteenth moon was called the walnut moon, and it was during that month that they cracked their nuts.

Again, referring to the uses made of walnuts by the Virginia Indians, Hariot ${ }^{16}$ says:

They break them with stones, and pound them in mortars with water to make a milk, which they use to put into some sorts of their spoonmeat.

Again Jones says:

Bernard Romans ${ }^{17}$ assures us that the Florida Indians used hickory nuts in plenty making from them a milky liquid of which they were very fond, and which they ate with sweet potatoes.

It is interesting to record the fact that the Hon. W. T. Robertson, former mayor of Montgomery, has told the writer that he recalls that a Negro woman, a former slave, often employed this same process, pounding the nuts in a mortar and grinding with water to secure a milky emulsion with the oil in the nuts which was very palatable. This slave was familiar with many of the native medicines and remedies for the treatment of the sick, and oftentimes was able to cure loathsome diseases that had been given up by white physicians.

Such was the extent of the oil manufactured by the natives, that it became an article of commerce soon after the arrival of European traders, and was regularly exported. Bartram mentions meeting a caravan of pack horses, carrying skins filled with

\footnotetext{
${ }^{13}$ Narratives of the Career of Hernando de Soto, Smith's translation, New York, 1871, p. 90. p. 90.

${ }^{14}$ Relation of .llvar Nuñez Cabeça de Vaca, Smith's translation, New York, 1871,

${ }^{15}$ See Du Pratz, History of Louisiana, London, 176.3, vol. II, p. 195.

${ }^{16} \mathrm{~A}$ Brief and True Report, Frankfort, 1590, p. 18.

${ }^{17}$ Romans, Natural History of East and West Florida, New York, 1775, p. 68.
} 
oil, bound for the Atlantic coast. In 1798-9, Hawkins in his "Sketch of the Creek County," records the trading value of a bottle of oil of hickory-nut to be 75 cents, when at the same time pork was $\$ 4.00$ per cwt., which would make a bottle of this oil equal nearly 19 lbs. of pork. The trade bottle of that day was the whiskey bottle, of very heary glass, black in color, squat in shape, and with a very deep deceptive depression under the bottom. Its capacity, originally possibly a quart, had dwindled to $1^{3}+$ pints. It is of record that an Ohio soldier, in training at Camp Sheridan in 1918, unearthed on the Connelly place near Montgomery, one of these bottles, actually containing some of the oil.

2. In paints. In ceremonies and for personal adornment, as well as for some of their utensils and implements, the Indians used paints to satisfy their desire for display. The base of all paint is a ground mineral or ore, mixed with some liquid material to cause it to be retained upon the surface on which it is applied. This process was known to the natives, and they used water, oil, or grease. For permanency the last two were used. They ground the mineral bases in cavities of hard flat stones of compact nature similar to those employed for cracking nuts, and they also used stone pestles in the same manner. The colors were red, black, vermilion, brown, yellow, and white. Most of these colors were obtained locally, from iron ores or various clays, or else were secured by trade from Indians of other regions. After the colors were ground, oil was mixed in and ground again. For applying the paint, we may well suppose that brushes were readily thought of and used, consisting of hair or bristles from the bear, deer, or other animals. Lawson ${ }^{18}$ refers to the Indians of North Carolina as follows:

Moreover they buy Vermillion of the Indian Traders wherewith they paint their Faces all over red, and commonly make a Circle of Black about one Eye, and another Circle of White about the other, whilst others bedawb their Faces with Tobacco-Pipe Clay, Lamp-black, black Lead and divers colors. . . . It is impossible ever to know an Indian under these colors although he has been in your Home a thousand times. . . . As for their Women, they never use any Paint on their Faces [What a commentary on the present!].

\footnotetext{
${ }^{18}$ Lawson, History of Carolina, London, 1714.
} 
The earthenware pots were often painted of a solid color, and others perhaps decorated. Broken portions of pots of solid red color are found at the present time in burials, and on the surface, the former particularly showing the color still well preserved.

3. In Leather Making or the Treatment of Skins. To preserve the skins of the wild game for their own uses, whether for adornment or personal wear, or for protection in sleeping and so forth, was the Indian's first desire. Strange to say, they were in many places acquainted with the action of certain barks to better preserve the skins of deer and bear, although they did not know the reason therefor, and leather by tanning was thus made in a primitive fashion. Jones ${ }^{19}$ tells as follows of the method of doing this:

They prepared their skins by first soaking them in water. The hair was then removed by the aid of a bone or stone scraper. Deer's brains were next dissolved in water, and in this mixture the skins were allowed to remain until they became thoroughly saturated. They were then gently dried and while drying, were continually worked by hand and scraped with an oystershell or some suitable stone implement to free them from every impurity and render them soft and pliable. In order that they might not become hard, when exposed to rain, they were cured in smoke, and tanned with the bark of trees. Young Indian-corn beaten to a pulp answered the same purpose as the deers brains.

Lawson ${ }^{20}$ describes the practice of the Carolina Indians, as he found them, as follows:

They wear shoes of Bucks, and some of Bears skins, which they tan in an Hour or two, with the Bark of Trees boil'd, wherein they put the Leather whilst hot, and let it remain a little while, whereby it becomes so qualify'd as to endure Water and Dirt without growing hard.

Salt is used at the present time in drying out the skin, when it is desired to preserve the hair, by rubbing on its under side. This dries out the raw skin, causes the constriction of the hair follicles, and so prevents the hair being lost. After being dried, it is worked by hand to make it pliable, and finally it is rubbed down with oil in order to make the quality permanent.

Without doubt this plan was in use by the Gulf Coast Indians,

${ }^{19}$ Jones, op. cit., p. 62.

${ }^{20}$ Lawson, op. cit. 
and probably others. Mention is made by the Gentleman of Elvas ${ }^{21}$ of an experience at Cayas, in the present State of Texas:

The salt is made along by a river, which when the water goes down, leaves it upon the sand. As they cannot gather the salt without a large mixture of sand, it is thrown together in certain baskets they have for the purpose, made large at the mouth and small at the bottom. These are set in the air on a ridge pole, and water being thrown on, vessels are placed under them wherein it may fall; being strained and placed on the fire, it is boiled away, leaving salt at the bottom.

That salt was used in the same region was very evident, for mention is made ${ }^{22}$ of the skins in use at that place:

Three Indians came the next day with loads of cow-skins, and three days afterward came twenty others. . . . He brought a present of many cowskins, which were found very useful; the country being cold, they were taken for bed covers, as they were very soft and the wool like that of sheep. Near by, to the northward, are many cattle.

4. For bodily health. The Indians used bear fat and other oils to rub the body in order to make the skin supple and healthy. That they used oil internally is not stated, but they without doubt knew its value, on account of the large use it had as a food. Jones, ${ }^{23}$ speaking of the Georgia Indians, writes:

Oglethorpe shortly after the settlement of Savannah, speaking of the Indians food there, declares that they, as the ancient Germans did, anoint with oil and expose themselves to the sun, which occasions their skins to be brown of color. The men paint themselves of various colors, red, blue, yellow and black.

5. In hair dressing. This was also practised, and bear fat was used largely for the purpose. Lawson ${ }^{24}$ comments on the practice in 1700 by writing:

Their Dress in Peace and War is quite different. Besides, when they go to war, their Hair is comb'd out by the Women and done over very much with Bears Grease and red Root. . .

6. For the rubbing and polishing of ornaments and implements. Although we have no direct authority for the statement, we may be sure that the ornaments and implements bearing a polish which

${ }^{21}$ Narratives of De Soto, New York, vol. I, pp. 135-136.

${ }^{22}$ Ibid., pp. 139-140.

${ }^{23}$ Jones, op. cit., p. 257.

${ }^{24}$ Lawson, loc. cit. 
has remained to this day were polished by the use of oil or grease, after the shape of the ornament or implement was secured by rough grinding with other stones. An additional rubbing after oiling would give the desired polish. In the many examples of finely polished hammer stones, ceremonial axes, gorgets, and other articles which we have at the present time, we can be reasonably sure they were polished in this manner. The natives gave to their bows the closest attention, for they were their main dependence in war and in the chase. The choicest woods were carefully selected, shaped, and preserved, and Jones ${ }^{25}$ tells us that they were "frequently anointed with bears grease to render them flexible and keep them from cracking and breaking."

$\begin{array}{cccc}\text { Yield of OIL From Nuts } & \\ \text { Black II } 6 & \\ \text { (Juglans } & \text { Hickory Nut } & \text { Cotton Seed } & \text { Peanuts } \\ \text { nigra) } & \text { alba) } & \text { (Upland } & \text { (Runner } \\ & \text { variety) } & \text { variety) }\end{array}$

\begin{tabular}{|c|c|c|c|c|}
\hline $\begin{array}{l}\text { Wt. in grams } \\
\text { per } 50 \text { nuts }\end{array}$ & 531. & 325.5 & 5.5 & 56.8 \\
\hline $\begin{array}{l}\text { Number of nuts } \\
\text { to the Ib. }\end{array}$ & 42 & 69 & 4100 & 511 \\
\hline $\begin{array}{l}\text { Proportion percent- } \\
\text { age of kernels in } \\
\text { whole nut. }\end{array}$ & 10.26 & 19.50 & 53.50 & 73.15 \\
\hline $\begin{array}{l}\text { Percentage of } \\
\text { oil in kernels }\end{array}$ & 50.30 & 67.42 & 36.25 & 46.60 \\
\hline $\begin{array}{l}\text { Percentage of am- } \\
\text { monia in kernels }\end{array}$ & 6.56 & 2.17 & 6.25 & 5.45 \\
\hline $\begin{array}{l}\text { Percentage of pro- } \\
\text { tein in kernels }\end{array}$ & 33.72 & 11.16 & 32.13 & 28.00 \\
\hline $\begin{array}{l}\text { Available oil in } 100 \\
\text { lbs. whole nuts ( }\end{array}$ & )$^{0.625}$ & 1.20 & 2.10 & 3.88 \\
\hline
\end{tabular}

${ }^{25}$ Jones, op. cit., p. 257.

${ }^{26}$ Samples of both walnut and hickory nut oil were exhibited. They were produced by extraction with a solvent, which in this case was petroleum ether. Methods in use by the natives could not of course give an oil of the purity or appearance comparable to these examples. Samples of peanut oil, the native ground pea, and cotton seed oil were shown for comparison. All of these samples were of crude oil, and not refined by a chemical process. Refined oil by means of caustic of soda in the usual way was shown, as also oil bleached by standard fullers earth, great improvement over the crude oil being very evident. All of these processes were of course unknown to the ancients. 




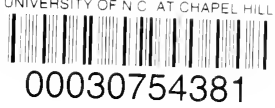

ト()R(

IHF NORIH( AR()IINA( ()III II ) N 


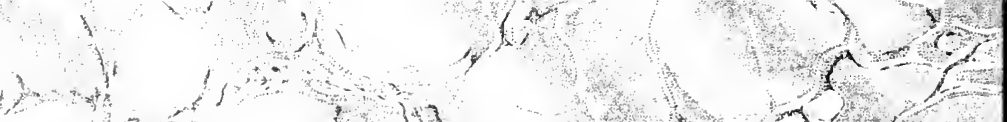

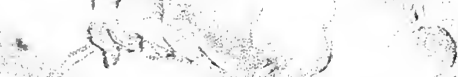
$c^{4+3}=-2$

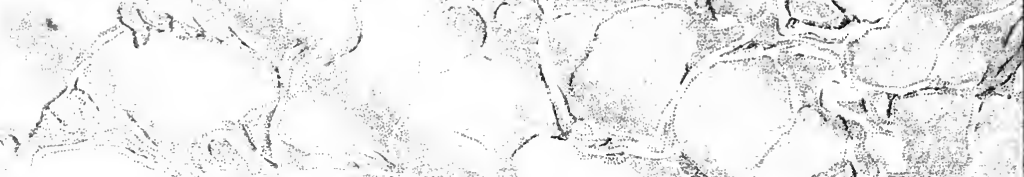

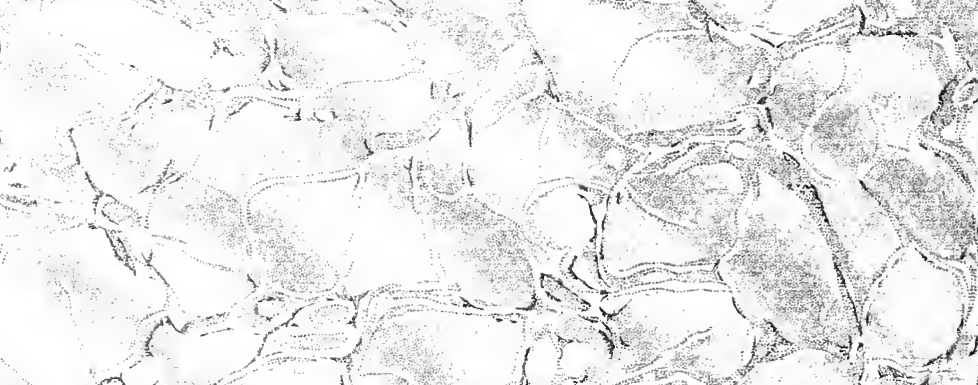

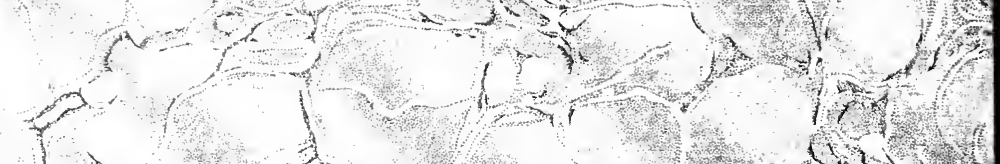

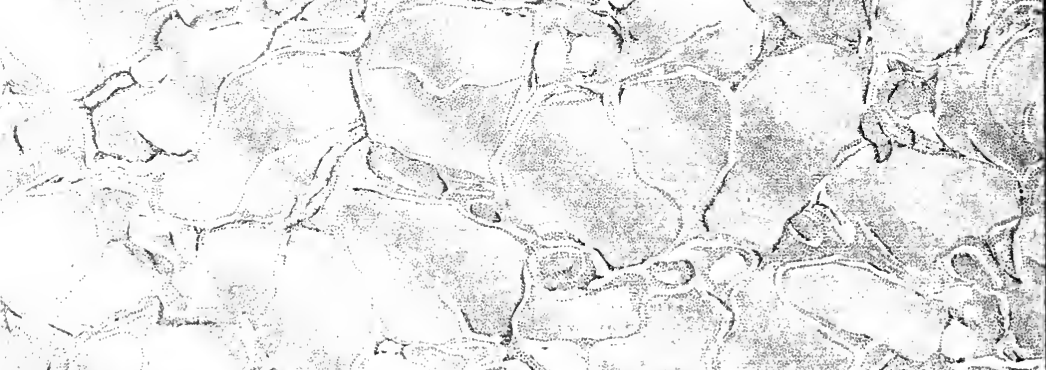

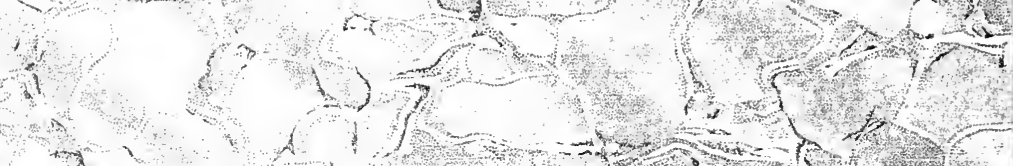

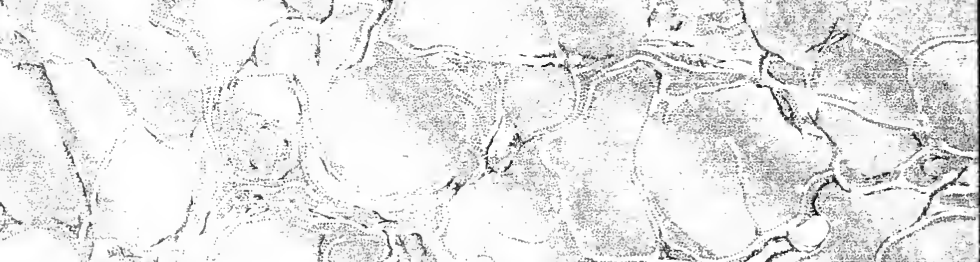

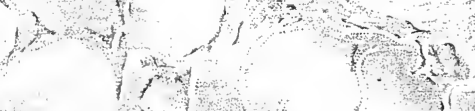

$-\infty b^{2}+2$

(1) (1)

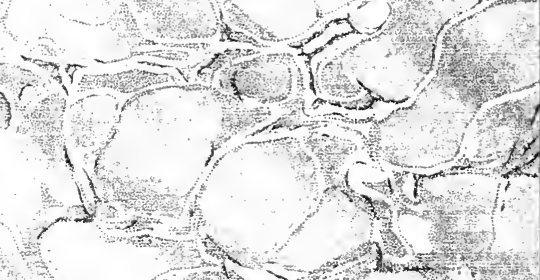
2

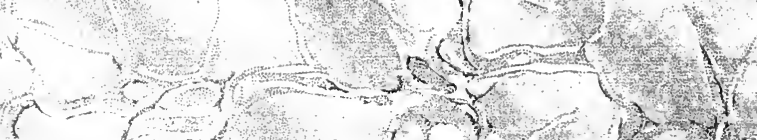
$r=1-p^{2}-12$

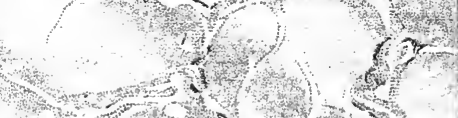
rits

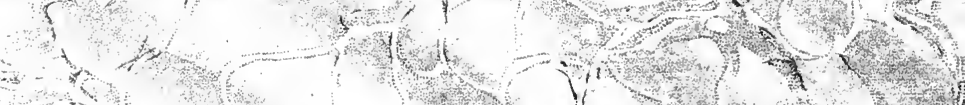
ty 